\title{
Through gender parity in scientific publications
}

María Luisa Jiménez-Rodrigo, Emilia Martínez-Morante, María del Mar García-Calvente and Carlos Álvarez-Dardet

J Epidemiol Community Health 2008;62;474-475 doi:10.1136/jech.2008.074294

Updated information and services can be found at:

http://jech.bmj.com/cgi/content/full/62/6/474

\section{These include:}

References This article cites 7 articles, 3 of which can be accessed free at: http://jech.bmj.com/cgi/content/full/62/6/474\#BIBL

Rapid responses You can respond to this article at:

http://jech.bmj.com/cgi/eletter-submit/62/6/474

Email alerting Receive free email alerts when new articles cite this article - sign up in the box at service the top right corner of the article

\section{Notes}

To order reprints of this article go to:

http://journals.bmj.com/cgi/reprintform

To subscribe to Journal of Epidemiology and Community Health go to:

http://journals.bmj.com/subscriptions/ 


\section{Through gender parity in scientific publications}

\author{
María Luisa Jiménez-Rodrigo, ${ }^{1}$ Emilia Martínez- \\ Morante, ${ }^{2}$ María del Mar García-Calvente, ${ }^{2}$ \\ Carlos Álvarez-Dardet ${ }^{3}$
}

Despite increased numbers of female researchers, women still face more difficulties than their male counterparts when it comes to publishing their work and having it read and cited. In this editorial, the main recommendations are detailed in order to promote gender parity in the scientific arena. Specifically, we must review the make-up of the editorial boards responsible for the publication processes, the evaluation process and the review criteria in place for scientific works.

\footnotetext{
She didn't write it.

She wrote it, but she shouldn't have.

She wrote it, but look what she wrote about.

She wrote it, but she wrote only one of it. She wrote it, but she isn't really an artist, and it isn't really art.

She wrote it, but she had help.

She wrote it, but she's an anomaly.

She wrote it, BUT...

Joanna Russ, 1983. Quoted in Margaret

Rossiter 1993.
}

Almost 25 years have passed since these words were first written and, despite increased numbers of female researchers, women still face more difficulties than their male counterparts when it comes to publishing their work and having it read and cited. The proportion of biomedical articles with a woman as the main author is around $30 \%$, and there are marked differences between specialties. ${ }^{12}$ Women are still under-represented in the editorial boards of health magazines, especially in terms of the most prestigious jobs involving the most responsibility, and less than $20 \%$ of directors' posts in scientific societies are held by women. ${ }^{3-5}$ The gap between the contributions made by men

\footnotetext{
${ }^{1}$ Department of Sociology, University of Sevilla, Spain

${ }^{2}$ Andalusian School of Public Health, Granada, Spain;

${ }^{3}$ Journal of Epidemiology and Community Health and Department of Public Health, University of Alicante, Spain
}

Correspondence to: Maria del Mar García-Calvente, Escuela Andaluza de Salud Pública, Campus Universitario de Cartuja, Apartado de Correos 2070, E-18080 Granada, Spain; mariadelmar.garcia.easp@juntadeandalucia.es publication process. inequality which favours women. and those made by women in the processes for the publication of scientific articles relating to health (fig 1) clearly demonstrates that gender parity is still a matter that needs to be addressed. It is therefore very important to identify and correct the mechanisms of sexist discrimination that are affecting the processes of developing and promoting knowledge and, specifically, the publishing process.

Gender plays a disproportionately important role in the "likelihood that a person enters the scientific community, stays in it and sees their work recognised $[\ldots]$ and enjoys the benefits of a scientific career". ${ }^{6}$ This phenomenon has been dubbed the Matilda effect, ${ }^{7}$ a feminised version of the term Matthew effect, coined by sociologist Robert Merton. This discrimination has been explained by the segregation-both vertical, horizontal, contractual and temporal - of women in scientific professions, the influence of sexist stereotypes in science and the persistent androcentrism in the organisation and evaluation of research work. ${ }^{4} 6$

The classification of scientific excellence in terms of productivity, defined in accordance with the number of works published by an author, their impact factor and the frequency with which they are cited in other works makes it difficult for scientists to compete in equal conditions ${ }^{8}$ because a number of bibliometric privileges that work in favour of men, or the "male bonus", are still inherent in the system itself. We must not forget that the publication and citation process is influenced by criteria related to an author's talent and capability, and by other key deciding factors, such as social capital, active participation and the distribution of power in scientific networks. In addition to the fact that men have greater access to social resources as well as the time and material resources required to invest in a career in research, ${ }^{9}$ authors commonly cite other, highly renowned authors, who are usually male, and male researchers tend to prefer to cite their

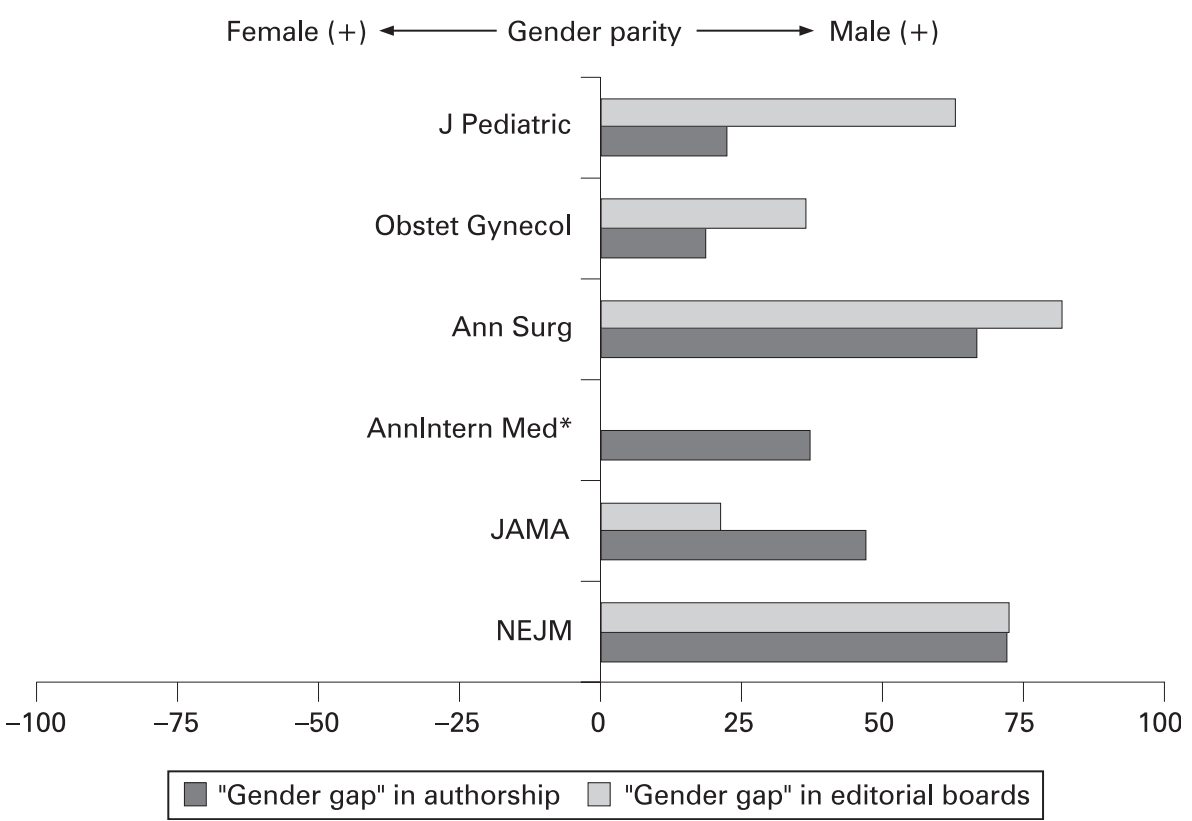

Figure 1 Gender gap $\dagger$ in relation to the participation of female and male researchers in the

${ }^{*}$ No data regarding editorial boards are available. Sourece: Created by the authors based on data from Jagsi et $\mathrm{al}^{1}$ and Morton and Sonnad. ${ }^{5}$

$\dagger$ The "gender gap" concept is a basic indicator used to carry out a gender analysis in any given situation. It represents the difference between the percentages of men and women, and measures the size of the gap between the two sexes, to create a visual representation of situations of inequality and discrimination. A result of zero indicates gender parity. A positive result shows that there is gender inequality which favours men, and a negative result shows that there is gender 


\section{Box 1 Recommendations to make progress in gender parity in publication process}

1. Promote the presence and participation of women in the editorial boards of magazines, at all levels (scientists, writers, honorary members, etc...) and for all lines of research (both "soft" and "hard"). If necessary, provisional measures of positive action could be put into place, such as the payment of membership fees.

2. Secure greater impartiality and independence in the evaluation procedures with regard to the identities and characteristics of the authors, such as their sex, nationality, work centre, etc... This could be done by, for example, setting up a blind evaluation system.

3. Be aware of and avoid the influence of sexist prejudices and stereotypes through measures such as the provision of training and promotion of awareness of matters relating to gender parity amongst the people involved in the review of works and in editorial policies and the provision of evaluation tools which promote gender equality in review processes.

4. Periodically analyse and evaluate the impact that review processes have on gender parity with a view to identifying sexist biases and discriminatory practices.

5. Include equal opportunities for both sexes as a basic, inalienable principle in the ethical code for editorial practices.

6. Expand editorial lines which promote, to a greater extent, the publication of multidisciplinary research and emerging themes such as gender studies.

7. Demand information about the type of contribution made by each author of a manuscript so that the contribution made is reflected thought the order in which the authors' names are listed.

8. Specify the sex of the authors and people quoted in the manuscripts by including their full names in the list of authors and in the bibliographical references.

male counterparts. ${ }^{10}$ Editorial boards are also criticised for the lack of support they give to research carried out and published by women. ${ }^{10}$

Furthermore, the peer review process, which is a central mechanism used to evaluate and promote scientific excellence, is also criticised because of the influence of sexist, androcentric biases that have a negative effect upon the scientific careers of women. ${ }^{11}{ }^{12}$ These prejudices translate into double standards in the evaluation of the scientific competence of men and women. ${ }^{13}$ As such, work produced by female researchers is met with a greater lack of interest, more disapproval or silencing and more negative criticism and corrections than work produced by their male counterparts. ${ }^{9}{ }^{12}$ In addition, women tend to work on soft lines of research, and are assigned subordinate, auxiliary and temporary roles. It is also common for the results of research carried out by women to be attributed to men, and for unfounded assumptions to be made about the difficulties they have in fitting into scientific dynamics and environments, based on women's possible family responsibilities. ${ }^{14}$ Within the framework of these prejudices, there is still a tendency to undervalue and marginalise studies regarding gender and women. ${ }^{15}$ Having said that, the bias that threatens the development of real equal opportunities to the greatest extent is almost certainly the defence of what is known as gender neutrality, as an extension of the irrefutable principles of objectivity, neutrality, impartiality and the pre-eminence of the merit and capacity of the hegemonic model of doing science.

As a result, for a number of social and ethical reasons we must not delay in applying a series of measures in order to promote gender parity in the scientific arena. Specifically, we must review the make-up of the editorial boards responsible for the publication processes, the evaluation process and the review criteria in place for scientific works. The main recommendations are detailed in box 1 .

In addition to these recommendations, the basic keys to change include strengthening and demanding greater transparency and publicity in editorial policies and in the manuscript review processes and, above all, the promotion of greater awareness of sexual discrimination. Therefore, in order to achieve gender parity, editorial organisations, forums and boards, especially, given their influence in academic circles, the Vancouver Group or the COPE (Committee on Publication Ethics), must show a clear, firm willingness to refer to and discuss the gender gap problem in their publications. Scientific publications play an essential role when it comes to visualising, recognising and promoting the work of female researchers and helping to make progress in gender parity in the processes of constructing and publishing scientific knowledge.

Competing interests: None declared
J Epidemiol Community Health 2008:62:474-475 doi:10.1136/jech.2008.074294

\section{REFERENCES $\boldsymbol{S}^{\mathrm{T}}$}

1. Jagsi Reshma, Guancial Elizabeth, Cooper Cynthia, et al. The "gender gap" in authorship of academic medical literature - a 35-year perspective. N Engl J Med 2006;355:281-7.

2. Schiaffino Anna, García M, Fernández Esteve (en nombre del Grupo de Género y Salud Pública de SESPAS). Autoría y presentación de resultados según el género en cuatro revistas biomédicas españolas. Gac Sanit 2001;15:251-4.

3. Kennedy Barbara, Ling Yin, Dickstein Leah. Women on the editorial boards of major journals. Acad Med 2001;76:849-51

4. Ortiz-Gómez Teresa, Birriel-Salcedo Johanna, Ortega del Olmo Rosa. Género, profesiones sanitarias y salud pública. Gac Sanit 2004;18/Suppl 1):189-94.

5. Morton Melinda, Sonnad Seema. Women on professional society and journal editorial boards. J Natl Med Assoc 2007;99:764-71.

6. Osborn Mary, Rees Teresa, Bosch Mineke, et al. Política científica de la Unión Europea. Promover la excelencia mediante la integración de la igualdad entre géneros. Informe del Grupo de trabajo de ETAN sobre las mujeres y la ciencia. Luxemburgo: Oficina de Publicaciones Oficiales de las Comunidades Europeas 2001. ftp://ftp.cordis.europa.eu/pub/improving/docs/ g_wo_etan_es_200101.pdf (accessed 3 Jun 2007)

7. Rossiter Margaret. The Matthew Matilda effect in science. Soc Stud Sci 1993;23:325-41.

8. Brouns Margo. Gender and the assessment of scientific quality. In: European Commission.Gender and Excellence in the Making. Luxembourg: Office for Official Publications of the European Communities 2004:147-54 http://ec.europa.eu/research/sciencesociety/pdf/bias_brochure_final_en.pdf laccessed 3 Jun 2007).

9. Thorvaldsdóttir Thorgerdur. Engendered opinions in placement committee decisions. In: European Commission.Gender and Excellence in the Making Luxembourg: Office for Official Publications of the European Communities, 2004:101-8.

10. Addis Elisabetta. Gender in the publication process: evidence, explanations, and excellence. In: European Commission.Gender and Excellence in the Making. Luxembourg: Office for Official Publications of the European Communities, 2004:93-100.

11. Wenneräs Christine, Wold Agnes. Nepotism and sexism in peer-review. Nature 1997;387:341-3.

12. Davo Maria del Carmen, Vives Carmen, ÁlvarezDardet Carlos. Why are women underused in the JECH peer review process? J Epidemiol Community Health 2003;57:936-7.

13. Foschi Marta. Blocking the use of gender-based double standards for competence. In: European Commission.Gender and Excellence in the Making Luxembourg: Office for Official Publications of the European Communities, 2004:51-6.

14. WISELI (Women in Science and Engineering Leadership Institute) - UNIVERSITY OF WISCONSIN- Reviewing Applicants: Research on Bias and Assumptions. www.wiseli.engr.wisc. edu/initiatives/hiring/Bias.pdf (accessed 7 Jun 2006)

15. Rees Teresa. Measuring excellence in scientific research: the UK Research Assessment Exercise. In: European Commission.Gender and Excellence in the Making. Luxembourg: Office for Official Publications of the European Communities, 2004:115-20.

Detailing the scientific contributions made by men and women is essential in order to promote gender equality in publication processes, and as such the first names of authors have been included in the bibliography. 